\title{
Three new species, a lectotype designation, and taxonomic and geographic notes in Eburiini (Coleoptera, Cerambycidae, Cerambycinae)
}

\author{
Juan Pablo BOTERO \\ Departamento de Entomologia, Museu Nacional, Universidade Federal do Rio de Janeiro, UFRJ, \\ Quinta da Boa Vista, São Cristóvão, CEP 20940-040, Rio de Janeiro, RJ, Brazil. \\ E-mail: jp bot@yahoo.com \\ urn:lsid:zoobank.org:author:463CA17F-AC2C-44DF-85AB-2AEA79684A12
}

\begin{abstract}
Three new species of Eburiini are described: Beraba hovorei sp. nov. from Ecuador, Eburella migueli sp. nov from Colombia and Susuacanga marcelae sp. nov. from Mexico. A new combination, Quiacaua vespertina (Monné \& Martins, 1973) comb. nov., and the transfer of Eburia (Eburia) stroheckeri Knull, 1949 to Eburia (Eleutho) Thomson, 1864 are proposed. A key to species of Beraba Martins, 1997, Eburella Monné \& Martins, 1973 and Quiacaua Martins, 1997 is provided. Moreover, the geographical distribution for 15 species of Eburiini is expanded. A lectotype and a paralectotype for Volxemia dianella Lameere, 1884 are designated.
\end{abstract}

Keywords. Beraba, Eburella, Quiacaua, Susuacanga, Volxemia.

Botero J.P. 2015. Three new species, a lectotype designation, and taxonomic and geographic notes in Eburiini (Coleoptera, Cerambycidae, Cerambycinae). European Journal of Taxonomy 148: 1-22. http://dx.doi.org/10.5852/ ejt.2015.148

\section{Introduction}

The tribe Eburiini was proposed under the name "Éburiites" by Blanchard (1845) and was characterized by the simple, spineless antennae, enlarged terminal palpomeres and short, relatively unprojected genae. Eburiini is currently composed of 22 genera and 255 species, all with geographical distribution restricted to North, Central (including the Caribbean) and South America. Eburia Lacordaire, 1830 and Eburodacrys White, 1853 are the largest genera, comprising about $75 \%$ of the species of the tribe (87 and 89 species, respectively) (Botero 2015; Monné 2015).

In this work, one species of Beraba Martins, 1997, one species of Eburella Monné \& Martins, 1973 and one species of Susuacanga Martins, 1997 are described. Eburodacrys vespertina Monné \& Martins, 1973 is transferred to Quiacaua Martins, 1997, new combination. Eburia stroheckeri Knull, 1949, currently allocated in the nominative subgenus, Eburia, is transferred to Eburia (Eleutho) Thomson, 1864. The geographical distribution is expanded for 15 species. The keys proposed by Martins, 1999 for the genera Beraba, Eburella and Quiacaua are modified to include the new species. 


\section{Material and methods}

The material originated from the following institutions, which are subsequently referred to by their acronyms:

$\mathrm{BMNH}=$ The Natural History Museum, London, United Kingdom

CASC = California Academy of Sciences, San Francisco, California, United States of America

$\mathrm{IAVH}=$ Instituto de Investigaciones de Recursos Biológicos "Alexander von Humboldt", Villa de Leyva, Colombia

INPA = Coleção Sistemática de Entomologia, Instituto Nacional de Pesquisas da Amazônia, Manaus, Amazonas, Brazil

IRSNB = Institut Royal des Sciences Naturelles de Belgique, Brussels, Belgium

LGBC = Larry G. Bezark Collection, Sacramento, California, United States of America

MNRJ = Museu Nacional, Universidade Federal do Rio de Janeiro, Rio de Janeiro, Brazil

MZSP = Museu de Zoologia, Universidade de São Paulo, São Paulo, Brazil

The geographical distribution of the species follows the catalogue of Monné (2015). Pictures were taken with a Nikon D90 camera with Sigma $150 \mathrm{~mm}$ macro lens, optimized with Adobe Photoshop CS2 and combined with the program CombineZP.

\section{Results}

\section{Taxonomy}

Class Hexapoda Blainville, 1816

Order Coleoptera Linnaeus, 1758

Suborder Polyphaga Emery, 1886

Superfamily Chrysomeloidea Latreille, 1802

Family Cerambycidae Latreille, 1802

Subfamily Cerambycinae Latreille, 1802

Tribe Eburiini Blanchard,1845

Genus Beraba Martins, 1997

Beraba Martins, 1997: 67.

Beraba - Martins 1999: 178. — Galileo \& Martins 2000: 159. — Monné 2005: 137; 2012: 17.

\section{Type species}

Beraba moema Martins, 1997 (original designation).

\section{Remarks}

The genus Beraba was described by Martins (1997) to accomodate species previously assigned to Eburia. The genus was differentiated from Eburia by the apices of the meso- and metafemora with only an inner spine; integument shiny, antennomere III longer than IV, and the small size, generally smaller than Eburia species. Currently, the genus comprises 17 species.

The key to species of Beraba proposed by Martins (1999) is modified to include four species described subsequently after the publication of the key (B. inermis Martins \& Galileo, 2002; B. odettae Martins \& Galileo, 2008; B. pallida Galileo \& Martins, 2008 and B. tate Galileo \& Martins, 2010) and the new species, Beraba hovorei sp. nov. 
BOTERO J.P., New species and taxonomic and geographic notes in Eburiini

\section{Key to species of Beraba (modified and translated from Martins 1999)}

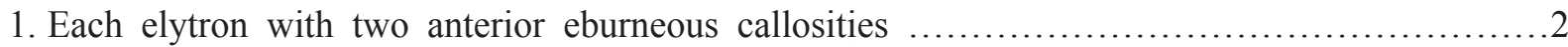

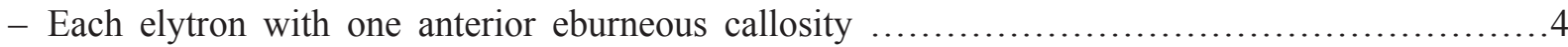

2. Tubercles of pronotum of same color as remainder of pronotum. Bolivia (Santa Cruz) B. pallida Galileo \& Martins 2008

- Tubercles of pronotum black (contrasting in color from remainder of pronotum) ............3

3. Tubercles of pronotum rounded at top; pronotum with fine and sparse pubescence; external posterior eburneous callosities starting ahead of inner posterior callosities, the last one surrounded by black area in its sutural side. Panama, Colombia ....

B. piriana Martins, 1997

- Tubercles of pronotum well projected and acuminated at top; pronotum glabrous; external posterior eburneous callosities starting at the same level as the inner posterior callosities, the last one not surrounded laterally by black area. Venezuela (Bolivar), Brazil (Amazonas) ...B. longicollis (Bates, 1870)

4. Elytra with eburneous callosities narrow and elongate; the external posterior callosity at least one third of elytral length and separated for the inner callosity by distance equivalent to the width of

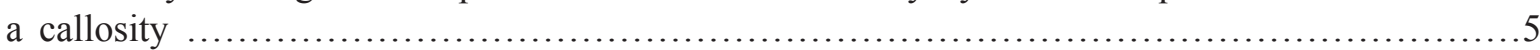

- Elytra with eburneous callosities elliptical, thicker and less elongate; the external posterior callosity slightly longer than the inner and separated for the inner callosity by distance smaller than the width of a callosity

5. Antennae and tibiae black; lateral spine of prothorax weakly projected; tubercles of pronotum concolorous with pronotal surface; external posterior callosity of elytra starting behind the inner posterior callosity. Brazil (Bahia, Minas Gerais, Espírito Santo) ......... B. grammica (Monné \& Martins, 1992)

- Antennae and tibiae brownish-orange or bicolored; lateral spine of prothorax clearly visible; tubercles of pronotum black; external posterior callosity of elytra starting ahead of inner posterior callosity ...6

6. Head, pronotum and most of the ventral region dark; antennae and tibiae bicolor; between anterior and posterior callosities with elytral costae visible. Ecuador (Manabi) ............ ho hovorei sp. nov.

- Head, pronotum, ventral region and tibiae brownish-orange; elytra without costae visible. Brazil (Bahia, Minas Gerais)

B. erosa (Martins, 1981)

7. Tubercles of pronotum of same color as remainder of pronotum

- Tubercles of pronotum black (contrasting in color from remainder of pronotum) ............10

8. The external posterior eburneous callosities of elytra placed at beginning of the apical third and distant from the inner callosities. Brazil (Rio de Janeiro)

B. angusticollis (Zajciw, 1961)

- The posterior eburneous callosities of elytra placed at same level

9. Prosternum and anterior region of pronotum smooth; elytral eburneous callosities long, the inner central slightly shorter than external; elytral costae not visible. Ecuador (Pichincha) ....

B. iuba Martins, 1997

- Posterior half of prosternum and anterior region of pronotum with punctures; elytral eburneous callosities small, external central twice length of the inner callosity; elytral costae visible. Ecuador (El Oro)

B. moema Martins, 1997

10. Apex and spines of femora of same color as remainder .11

- Apex and spines of femora black, contrasting with adjacent color ........................ 14

11. Surface of pronotum only with wrinkles or with wrinkles and some interspersed punctures $\ldots 12$

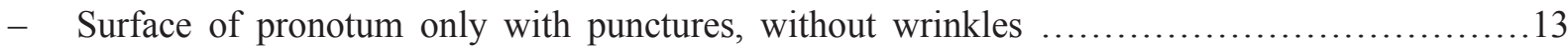


12. External posterior eburneous callosities at least twice length of inner; external apex of elytra unarmed. Colombia (Cundinamarca) B. inermis Martins \& Galileo, 2002

- Posterior eburneous callosities with similar size; apex of elytra with external spine. Colombia (Bolívar)

.B. marica Galileo \& Martins, 1999

13. Basal eburneous callosities narrowed and elongated; elytral costae visible behind posterior callosities. Bolivia (Santa Cruz) ............................. tate Galileo \& Martins, 2010

- Basal eburneous callosities shorted and subrounded; without elytral costae visible behind posterior callosities. Venezuela B. limpida Martins, 1997

14. Pronotum rugosely punctate .15

- Pronotum smooth or only with microsculpture

15. Scape black or darker than flagellomeres; prothorax with sides subparallel; eburneous callosities elongate and thin. Brazil (Goiás, Maranhão, Piauí)

B. decora (Zajciw, 1961)

- Scape with same color as flagellomeres, prothorax curved at sides or narrowed toward anterior margin; eburneous callosities elliptical

16. Lateral tubercle of prothorax small; posterior eburneous callosities starting anteriorly at same level; apex of elytra with black area. French Guiana

B. odettae Martins \& Galileo, 2008

- Lateral tubercle of prothorax long and acute; external posterior eburneous callosities starting behind inner posterior callosities; apex of elytra without black area. Peru

B. spinosa (Zajciw, 1967)

17. Prothorax longer than wide, anterior region of epipleura without projection, metafemora exceeding elytral apex. Brazil (Amazonas), French Guiana .... B. cauera Galileo \& Martins, 1999

- Prothorax as long as wide; anterior region of epipleura with projection, metafemora not exceeding elytral apex. Brazil (Mato Grosso do Sul), Bolivia (Cochabamba, Santa Cruz), Paraguay B. cheilaria (Martins, 1967)

\section{Beraba hovorei sp. nov. urn:1sid:zoobank.org:act:7050EB85-61D0-4898-9512-5D652837ABD4}

Fig. $1 \mathrm{~A}-\mathrm{C}$

\section{Differential diagnosis}

Beraba hovorei sp. nov. is similar to B. grammica and B. erosa in having only one eburneous callosity at the anterior region of each elytron and the posterior callosities narrow and elongated, the external one at least one-third of the elytral length and separated for the inner by distance equivalent to the width of a callosity. Beraba hovorei sp. nov. differs of both species by the color pattern: posterior region of head, most of prothorax, mesosternum, metasternum and urosternites dark; antennae, femora and tibiae bicolor; base of elytra and anterior and posterior region of posterior eburneous callosities black and and elytral costae visible between anterior and posterior callosities. In B. grammica and $B$. erosa the head, prothorax, mesosternum, metasternum and urosternites are brownish-orange, the antennae, femora and tibiae are unicolor (antennae, femora and tibiae brownish-orange in B. erosa and antennae and tibiae black and femora brownish-orange in $B$. grammica); elytra with black areas just surrounding the eburneous callosities, and without elytral costae visible between anterior and posterior callosities. Beraba hovorei sp. nov. differs from B. grammica in having the pronotal tubercles black (in $B$. grammica are of the same color than surface or pronotum) and by the external-posterior eburneous elytral callosities starting ahead the inner-posterior (in B. grammica the external posterior starts behind the inner posterior). 
BOTERO J.P., New species and taxonomic and geographic notes in Eburiini

\section{Etymology}

The species epithet is in honor of Frank T. Hovore, one of the collectors of the type series, for his contributions to the knowledge of the cerambycid fauna.
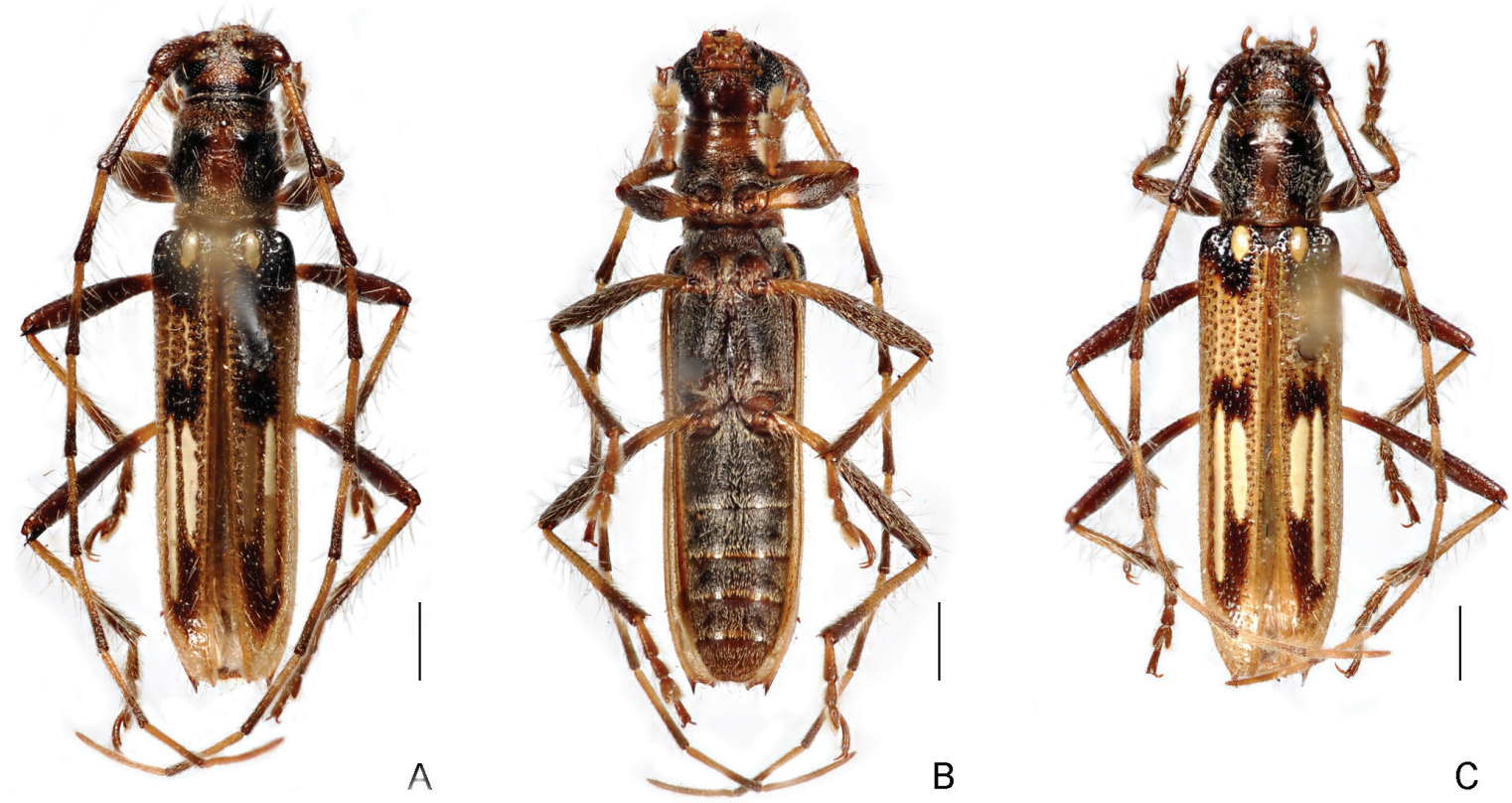

A
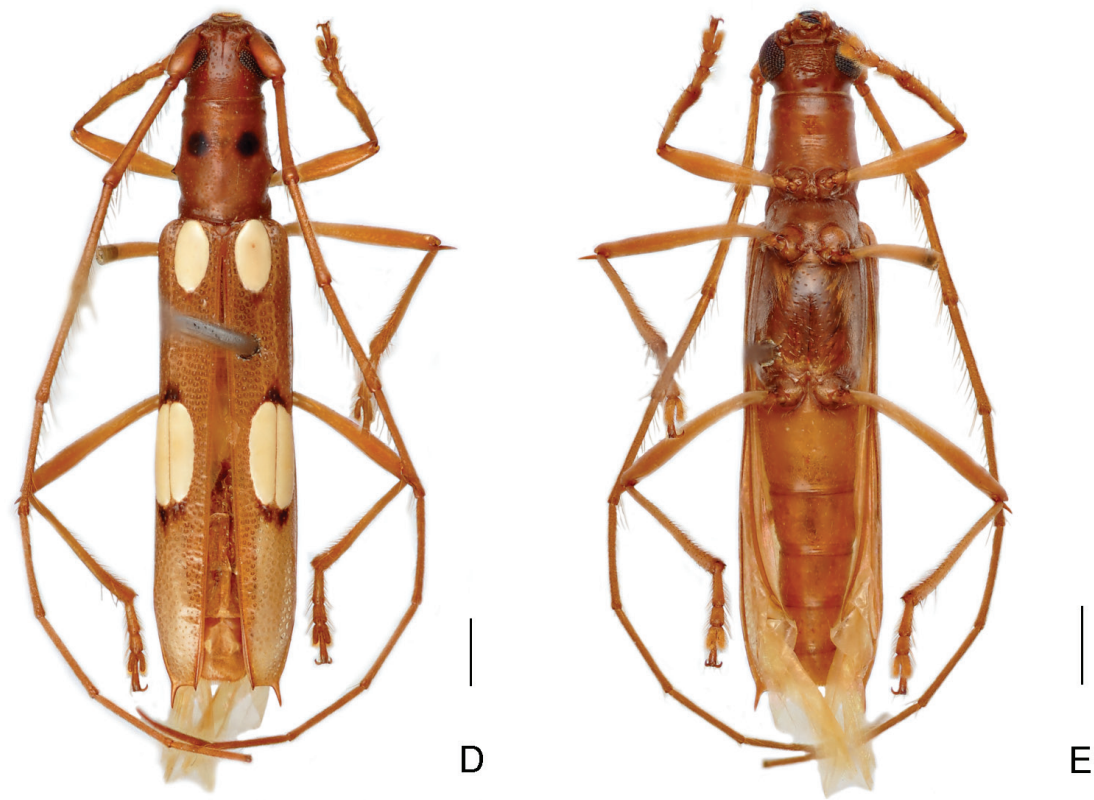

Fig. 1. A-C. Beraba hovorei sp. nov. A. Holotype, ô, dorsal view. B. Holotype, ô, ventral view. C. Paratype, $\uparrow$, dorsal view. - D-E. Eburella migueli sp. nov., holotype,, . D. Dorsal view. E. Ventral view. Scale bars $=1 \mathrm{~mm}$. 


\section{Material examined}

\section{Holotype}

ECUADOR, Manabi: ô, La Pila, 200 m, $01^{\circ} 11198$ S, $080^{\circ} 58068$ W, $18-27$ Feb. 2006, F.T. Hovore \& I. Swift leg. (CASC).

\section{Paratypes}

ECUADOR, Manabi: 3 우, La Pila, 200 m, $01^{\circ} 11198$ S, $080^{\circ} 58068$ W, $18-27$ Feb. 2006, F.T. Hovore

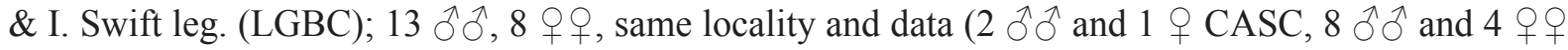

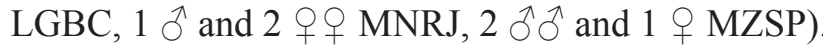

\section{Description}

Male

Integument brownish-orange. Ventrally dark. Posterior region of head, sides of pronotum, pronotal tubercles, base of elytra, anterior and posterior region of posterior eburneous callosities and elytral spines black. Antennomeres III-X, femora and tibia bicolored: antennomeres with basal half brownishorange and apical half light brown; femora light brown with base brownish-orange and tibiae brownishorange with apex light brown.

Body covered by long, erect and sparse setae, denser at inner face of basal antennomeres. Ventrally with dense grayish pubescence. Distance between upper lobes three times width of upper lobe. Antennae exceeding elytral apices at apex of antennomere VIII. Prothorax as long as width (including lateral tubercle), with lateral tubercle clearly visible, and acute. Pronotum with dense grayish pubescence, glabrous at center and with two anterior tubercles weakly elevated and rounded at top. Surface of pronotum with some shallow wrinkles.

Scutellum covered by dense grayish pubescence. Elytra about 3.5 times longer than prothorax; surface with coarse punctuation on basal half, finer and shallower towards to apex. Each elytron with three eburneous callosities: one basal, elliptical; and two posterior, narrow and elongate (the inner slightly wider than external), the external one at least one-third of elytral length, separated from inner by distance equivalent to width of a callosity, the external starting ahead the inner. Elytral costae visible between anterior and posterior callosities. Apex of elytra with external spine and with acute sutural projection.

Measurements (in mm)

Holotype, total length: 9.3 , prothorax length: 1.8 , prothorax width at its widest point: 1.7, elytral length: 6.5, humeral width: 2.0. Paratypes, $\widehat{O} / \Phi, \mathrm{n}=13 / 11$. Total length: $8.30 \pm 0.56 / 8.60 \pm 0.97$, prothorax length: $1.72 \pm 0.17 / 1.72 \pm 0.18$, prothorax width at its widest point: $1.51 \pm 0.11 / 1.55 \pm 0.22$, elytral length: $5.83 \pm 0.39$ / 6.08 \pm 0.69 , humeral width: $1.80 \pm 0.15 / 1.85 \pm 0.24$.

\section{Variability}

The black areas of elytra can be lighter; the dark area at the anterior and posterior region of the posterior eburneous callosities can expand between the callosities and surrounding the external margin of the external callosity. In females, the antennae exceeding elytral apices at antennomere X.

Genus Eburella Monné \& Martins, 1973

Eburella Monné \& Martins, 1973: 152.

Eburella - Martins 1997: 67; 1999: 146. — Monné 2005: 140; 2012: 17.

\section{Type species}

Eburella pumicosa Monné \& Martins, 1973 (original designation). 
BOTERO J.P., New species and taxonomic and geographic notes in Eburiini

\title{
Remarks
}

Eburella was described by Monné \& Martins (1973) for a single species, Eburella pumicosa Monné \& Martins, 1973; and characterized by the absence of pronotal tubercles; the presence, in males, of areas densely hairy at sternites I-IV and tarsomeres swollen. Later, Martins (1997) described Eburella pinima Martins, 1997 based on a single female; although he could not check the male characteristics, he justified the inclusion of the species in Eburella by the absence of the anterolateral tubercles of prothorax and the pronotal tubercles and the antennomere III without longitudinal sulcus. Later, Martins \& Galileo (1999) described a third species, Eburella longicollis Martins \& Galileo, 1999, based on a male specimen which did not have densely hairy areas on the sternites, considered by them as a specific characteristic. Recently, Botero (2013) described the male of Eburella pinima and noticed that the urosternites of males do not have densely hairy areas, corroborating the proposal of Martins \& Galileo (1999) that this is a specific characteristic. Currently, the genus is composed by three species and known from Bolivia, Brazil, Paraguay and Peru.

Key to species of Eburella (modified and translated from Martins 1999)

1. Surface of pronotum with sparse, very fine and very shallow punctures (almost imperceptible); apex of meso- and metafemora and femoral spine concolorous with body integument .............2

- Surface of pronotum with dense and coarse punctures (clearly visible); apex of meso- and metafemora and femoral spine black ........................................................

2. Body elongate and narrow; elytral length / width ratio greater than 4; sides of prothorax without spiniform tubercles; pronotum without black spots; eburneous elytral callosities short (shorter than scape). Peru, Bolivia (Santa Cruz) ...............................Eburella pinima Martins, 1997

- Body shorter; elytral length / width ratio less than 4; sides of prothorax with spiniform projection; pronotum with two black spots; eburneous elytral callosities long (longer than scape). Colombia (Cundinamarca, Vichada) Eburella miguelisp. nov.

3. Prothorax about as long as wide; distance between upper eye lobes four times width of upper eye lobe; males with densely hairy areas on sternites I-IV. Brazil (Mato Grosso, Mato Grosso do Sul), Paraguay, Bolivia (Santa Cruz) .....

E. pumicosa Monné \& Martins, 1973

- Prothorax longer than wide; distance between upper eye lobes twice width of upper eye lobe; males without densely hairy areas on sternites. Bolivia (Santa Cruz)

..Eburella longicollis Martins \& Galileo, 1999

\author{
Eburella migueli sp. nov. \\ urn:1sid:zoobank.org:act:57FB230D-962C-49C9-9F61-3944213C033D
}

Fig. 1D-E

\section{Differential diagnosis}

Eburella migueli sp. nov. is similar to E. pinima in having the surface of pronotum with sparse, very fine and very shallow punctures (almost imperceptible). It differs in having lateral tubercles at the prothorax (absent in E. pinima) and in having the apex and spine of femora black (reddish-orange in E. pinima). Eburella migueli sp. nov. differs from the other species of Eburella in having two black spots on the pronotum.

\section{Etymology}

The specific name is a genitive patronym in honor of my friend Miguel A. Monné, an inspiration to many budding cerambycidologists, for his work on the Neotropical Cerambycidae. Miguel is one of the authors of the Eburella genus. 


\section{Material examined}

Holotype

COLOMBIA, Cundinamarca: + , PNN Sumapaz, Cabaña Mirlas, 348’ N, 7352’ W, 710 m, 3-30 Apr. 2002, "Malaise", H. Vargas leg. (IAVH).

\section{Paratype}

COLOMBIA, Vichada: 1 ㅇ, PNN Tuparro, Cerro Tómas, 5²1’ N, 6751’ W, 141 m, 22 May-3 Jun. 2001, "Malaise", W. Villalba leg. (IAVH).

\section{Description}

Female

Integument reddish-orange. Apex of mandibles, two spots at anterior third of pronotum and anterior and posterior region of posterior eburneous callosities, black.

Distance between upper lobes three times width of upper lobe. Antennae exceeding elytral apices at antennomere VIII. Inner face of scape, pedicel, and antennomeres III-VI with long erect setae. Prothorax longer than wide (including lateral tubercle), with small lateral tubercle. Pronotum with long, erected and sparse yellow setae, surface with sparse, very fine and very shallow punctures, without wrinkles.

Prosternal process, mesosternum, mesepisternum, mesepimerum, metepisternum and lateral regions of metasternum covered with dense whitish pubescence. Elytra about four times longer than prothorax; surface with uniform, fine and shallow punctation. Each elytron with three eburneous callosities: one basal, elliptical; and two posterior, joined, equal in length and more elongate than basal callosities. Apex of elytra with external spine and with acute sutural projection.

Femora and tibiae fine and elongate; apical apex of meso- and metatibiae with long inner spine (longer than elytral spine). Sternites decreasing in length, the first one twice length of fifth, surface with sparse, long, white setae.

Measurements (in $\mathrm{mm}$ )

Holotype / paratype, total length: 10.8 / 11.0; prothorax length: 1.9 / 2.1, prothorax width at its widest point: 1.6 / 1.7, elytral length: 7.7 / 7.9, humeral width: 2.0 / 2.0.

\section{Variability}

The paratype has the posterior region of anterior eburneous callosities black.

\section{Remarks}

Eburella migueli sp. nov. is the first record of Eburella for Colombia.

Genus Eburia Lacordaire, 1830

Eburia Lacordaire, 1830: 177. Type species: Cerambyx quadrimaculatus Linnaeus, 1767.

Dissacanthus Hope, 1835: 107. Type species: Cerambyx quadrimaculatus Linnaeus, 1767.

Coeleburia Thomson, 1861: 237. Type species: Coeleburia semipubescens Thomson, 1861 (by monotypy).

Dissacantha Thomson, 1864: 240 (error). Type species: Cerambyx quadrimaculatus Linnaeus, 1767 (original designation).

Drymo Thomson, 1864: 242. Type species: Coeleburia pulverea Chevrolat, 1862 (monotypy).

Coeleburia - Thomson 1864: 240. — Martins 1997: 78. 
BOTERO J.P., New species and taxonomic and geographic notes in Eburiini

Dissacanthus - Lacordaire 1868: 295.

Drymo - Lacordaire 1868: 292. — Martins 1997: 78.

Eburia - Audinet-Serville 1834: 8. - Laporte 1840: 243. - Blanchard 1845: 146. — LeConte 1850:

11; 1873a: 178; 1873b: 302. — Blanchard in Gay 1851: 462. — Strauch 1861: 129. — Thomson 1861: 237; 1864: 239, 449. — Lacordaire 1868: 293. — Bates 1870: 264; 1880: 19. — Chenu 1870: 311. — LeConte \& Horn 1883: 287. — Leng 1884: 115. — Blatchley 1910: 1022. — Bradley 1930: 229. — Knull 1946: 191. — Linsley 1962: 54. — Arnett 1962: 862, 880 — Chemsak \& Linsley 1963: 213. — Gilmour 1968: 107. — Zayas 1975: 60. — Martins \& Napp 1979: 93. — Villiers 1980: 275. — Monné 1993: 21; 2005: 140; 2012: 17. — Martins 1997: 78; 1999: 225. — Noguera 2002: 6. — Bousquet 2007: 619. - Touroult 2012: 72; 2014: 88.

Eburia (Eburia) - Martins 1997: 78. Type species: Cerambyx quadrimaculatus Linnaeus, 1767 (by subsequent designation Hope 1843: 189).

\section{Type species}

Cerambyx quadrimaculatus Linnaeus, 1767 (by subsequent designation Hope 1843: 189).

The genus Eburia was proposed by Lacordaire (1830) and characterized by Thomson (1861) in having antennomere III without sulcus, just shorter than IV, antennomere XI longer than X, prothorax with lateral spines, mesosteral process without tubercle and metafemora not reaching the elytral apex. Currently, the genus is comprised of 87 species and two subgenera: the nominative subgenus, Eburia ( 85 species), and the subgenus Eleutho Thomson, 1864 (two species). The genus Eleutho was described by Thomson (1864) for a single species, Eleutho consobrina (Jacquelin DuVal, 1857), and later synonymized by Martins (1999) with Eburia. Vitali (2007), describing the species Eburia (Eleutho) consobrinoides (Fig. 2A), realized a great similarity of this species with Eburia consobrina and proposed that Eleutho should be considered as a subgenus of Eburia. According to Vitali (2007), this subgenus is characterized "by deeply excavate scape, spined prothorax and extremely developed antennomere XI".

Eburia (Eleutho) stroheckeri Knull, 1949 new subgeneric assignment

Fig. 2B-C

Eburia stroheckeri Knull, 1949: 104.

Eburia stroheckeri - Linsley 1962: 62. — Chemsak 1977: 74. —Chemsak et al. 1992: 35. — Monné 1993: 34. — Monné \& Giesbert 1994: 41. — Browne \& Peck 1996: 2158. — Peck \& Thomas 1998: 117. — Thomas 1999: 1. — Noguera 2002: 14.

\section{Geographical distribution}

United States of America (Florida).

\section{Material examined}

UNITED STATES OF AMERICA, Florida: 1 Ô, Miami-Dade County, May 1953 (MNRJ); 1 \&, 14 May 1956, D.R. Paulson leg. (MNRJ); 1 đ̃, 29 May 1962 (MNRJ); 1 \&, Jun. 1964 (MNRJ); Hamilton County,, , Jun. 1964 (MNRJ).

\section{Remarks}

In addition to the characteristics mentioned by Vitali (2007), the subgenus Eleutho can be characterized and differentiated from the nominative subgenus, Eburia, by the scape and basal antennomeres being granulate, mainly in males (Fig. 2C), and by antennomeres III-IX with projection in the outer side of the apex (Fig. 2A). 

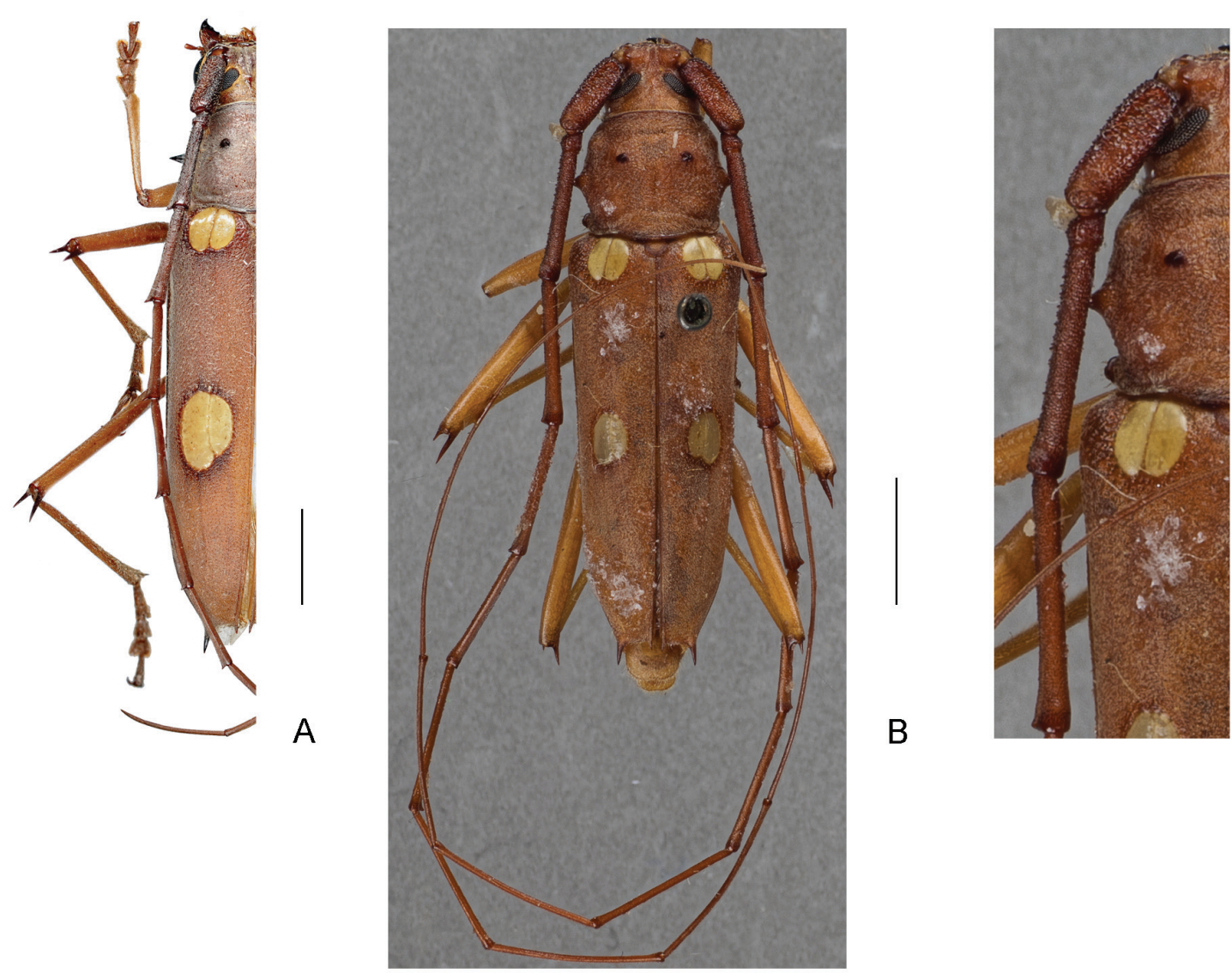

C
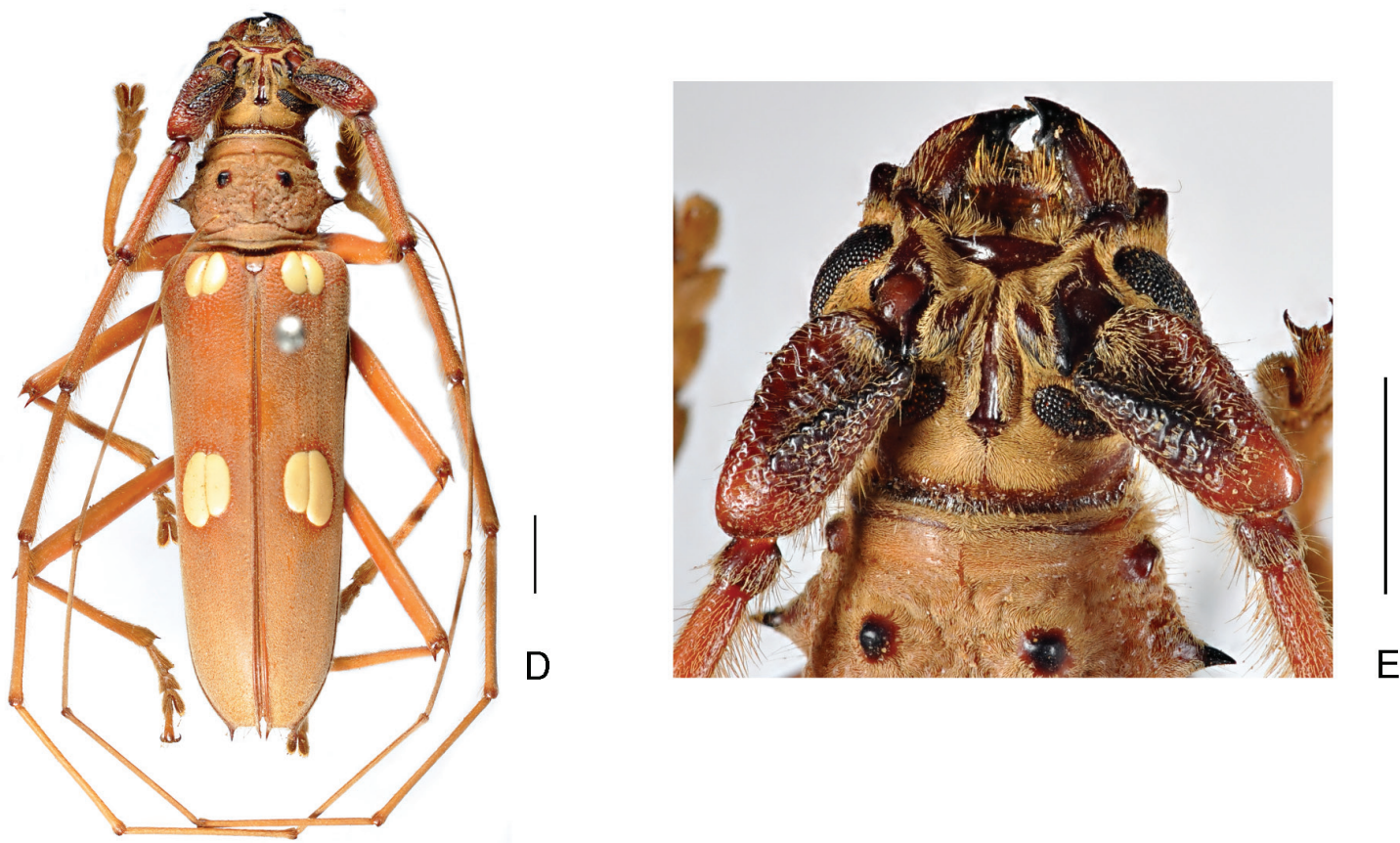

Fig. 2. A. Eburia (Eleutho) consobrinoides Vitali, 2007, syntype, + + - B-C. Eburia (Eleutho) stroheckeri Knull, 1949, holotype, O. B. Dorsal view. C. Detail of scape and basal antennomeres. D-E. Susuacanga marcelae sp. nov., holotype, $\widehat{O}$. D. Dorsal view. E. Detail of scape. Scale bars $=4 \mathrm{~mm}$. 
BOTERO J.P., New species and taxonomic and geographic notes in Eburiini

Examination of material of Eburia stroheckeri, including photographs of the holotype (Fig. 2B-C), allowed me to conclude that this species has the characteristics of Eburia (Eleutho) and I include it in that subgenus as a new subgeneric assignment.

Genus Susuacanga Martins, 1997

Susuacanga Martins, 1997: 60.

Susuacanga - Martins 1999: 134. — Monné 2005: 171; 2012: 18. — Botero 2014: 519 (rev.).

Type species

Cerambyx octoguttatus Germar, 1821 (original designation).

\section{Remarks}

Susuacanga was described by Martins (1997) to incorporate three South American species of Eburia. Recently, Tavakilian (2013) and Botero (2014) transferred other species to the genus and currently Sususacanga is composed by 12 species.

\section{Susuacanga marcelae sp. nov. urn:Isid:zoobank.org:act:65EDFB21-6E06-48D9-B84E-06739AF03FC3}

Fig. 2D-E

\section{Differential diagnosis}

Susuacanga marcelae sp. nov. is similar to S. poricollis (Chemsak \& Linsley, 1973) in having the median lateral tubercle of pronotum projected in a long spine, apex of meso- and metafemora with spines shorter than the pedicel and elytra with posterior eburneous callosities shorter than the length of the scape. Susuacanga marcelae sp. nov. differs by the integument being yellowish-orange, the anterior eburneous elytral callosities contiguous as in the same way the posterior and the elytral apices bispinose. In S. poricollis the integument is dark brown, the anterior eburneous elytral callosities are separated between them as in the same way the posterior and the elytral apices have only an inner spine. The scape strongly depressed (Fig. 2E) is a unique characteristic among the species of Susuacanga.

\section{Etymology}

The specific name is a genitive patronym in honor of my friend and mentor Marcela L. Monné, for all her support during my graduate studies and in recognition of her work on Cerambycidae.

\section{Material examined}

Holotype

MEXICO: $\sigma^{\Uparrow}$ [no other data] (IRSNB).

\section{Description}

Male

Integument yellowish-orange. Ventrally darker. Apices of mandibles, antennal tubercles, basal half of scape, lateral spine of prothorax, and pronotal tubercles black.

Body covered by dense, yellowish pubescence. Antennal tubercles glabrous, apex rhomboid. Distance between upper lobes twice width of upper lobe. Coronal suture glabrous, interocular tubercle barely elevated, divided by suture. Antennae exceeding elytral apices at apex of antennomere VI. Surface of scape very rugose, narrowing toward apex, dorsally at base strongly depressed. Inner face of scape, 
pedicel, and antennomeres III-VI with long erect setae, sparser to distal antennomeres. Antennal formula based on length of antennomere III: scape: 0.75 , pedicel: 0.17 , IV: 1.17 , V: 1.27 , VI: 1.35 , VII: 1.40 , VIII: 1.40, IX: 1.35, X: 1.35, XI: 2.92.

Prothorax transverse; antemedian lateral tubercle visible, glabrous and rounded at apex; median lateral tubercle projected in long and acute spine. Pronotum with dense grayish pubescence, with two anterior tubercles rounded at top; central gibbosity weakly elevated. Surface of pronotum with shallow wrinkles and punctures, obliterated by pubescence.

Elytra about four times longer than prothorax. Each elytron with four eburneous callosities: two basal, elliptical, contiguous, equal in size; and two posterior, elliptical, contiguous, the external slightly larger than inner; apices bispinose. Apex of meso- and metafemora bispinose, inner spine slightly longer than outer spine.

\section{Measurements (in mm)}

Total length: 38.5 , prothorax length: 6.1 , prothorax width at its widest point: 9.5 , elytral length: 26 , humeral width: 9.9 .

\section{Remarks}

According to the most recent key to species of the genus (Botero 2014), Susuacanga marcelae sp. nov. can be inserted into couple 9, as follows:

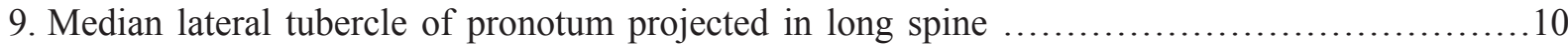

- Median lateral tubercle of pronotum rhomboid or slightly acute, but not spiniform ..............11

10. Integument dark-brown. Anterior eburneous elytral callosities separated between them as in the same way the posterior. Elytral apices with only an inner spine. Mexico (Michoacán, Puebla, Morelos, Guerrero, Oaxaca).

- Integument yellowish-orange. Anterior eburneous elytral callosities contiguous as in the same way the posterior. Elytral apices bispinose. Mexico

S. marcelae sp. nov.

Genus Quiacaua Martins, 1997

Quiacaua Martins, 1997: 70.

Quiacaua-Martins 1999: 175. — Monné 2005: 170; 2012: 18.

\section{Type species}

Eburia abacta Martins, 1981 (original designation).

\section{Remarks}

The genus Quiacaua was described by Martins (1997) and characterized by the shiny integument, the scape subpiriform and with basal sulcus; the prothorax with lateral tubercles well developed and antero-lateral tubercles weakly developed; the surface of pronotum rugose-punctate; the mesosternum with tubercle; the elytral apex with a long external spine and a sutural projection and the meso- and metafemora with long inner spine. Currently, the genus is comprised of only two species.

\section{Key to species of Quiacaua (modified from Martins 1999)}

1. Posterior-central callus of pronotum strongly elevated (almost attaining height of pronotal tubercles); eburneous callosities of elytra elongate, the center separated between them; 
BOTERO J.P., New species and taxonomic and geographic notes in Eburiini

behind anterior eburneous callosities, in front and behind central eburneous callosities and at apex of elytra with dark areas. Brazil (Bahia, Minas Gerais, Espírito Santo, Rio de Janeiro) Q. vespertina (Monné \& Martins, 1973) comb. nov.
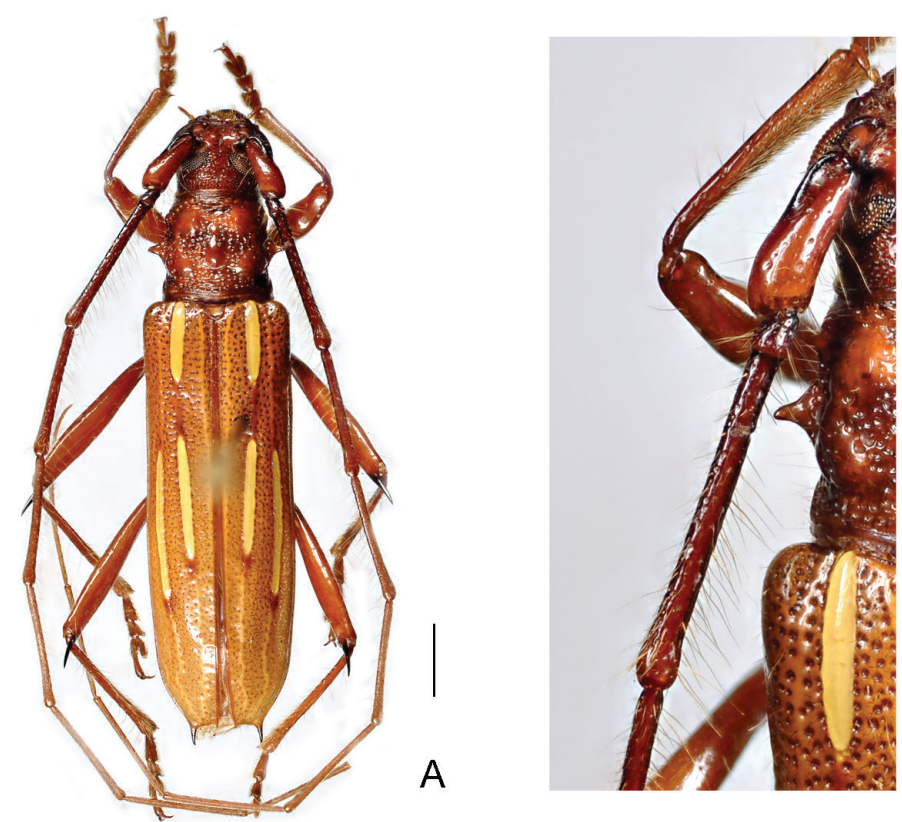

B
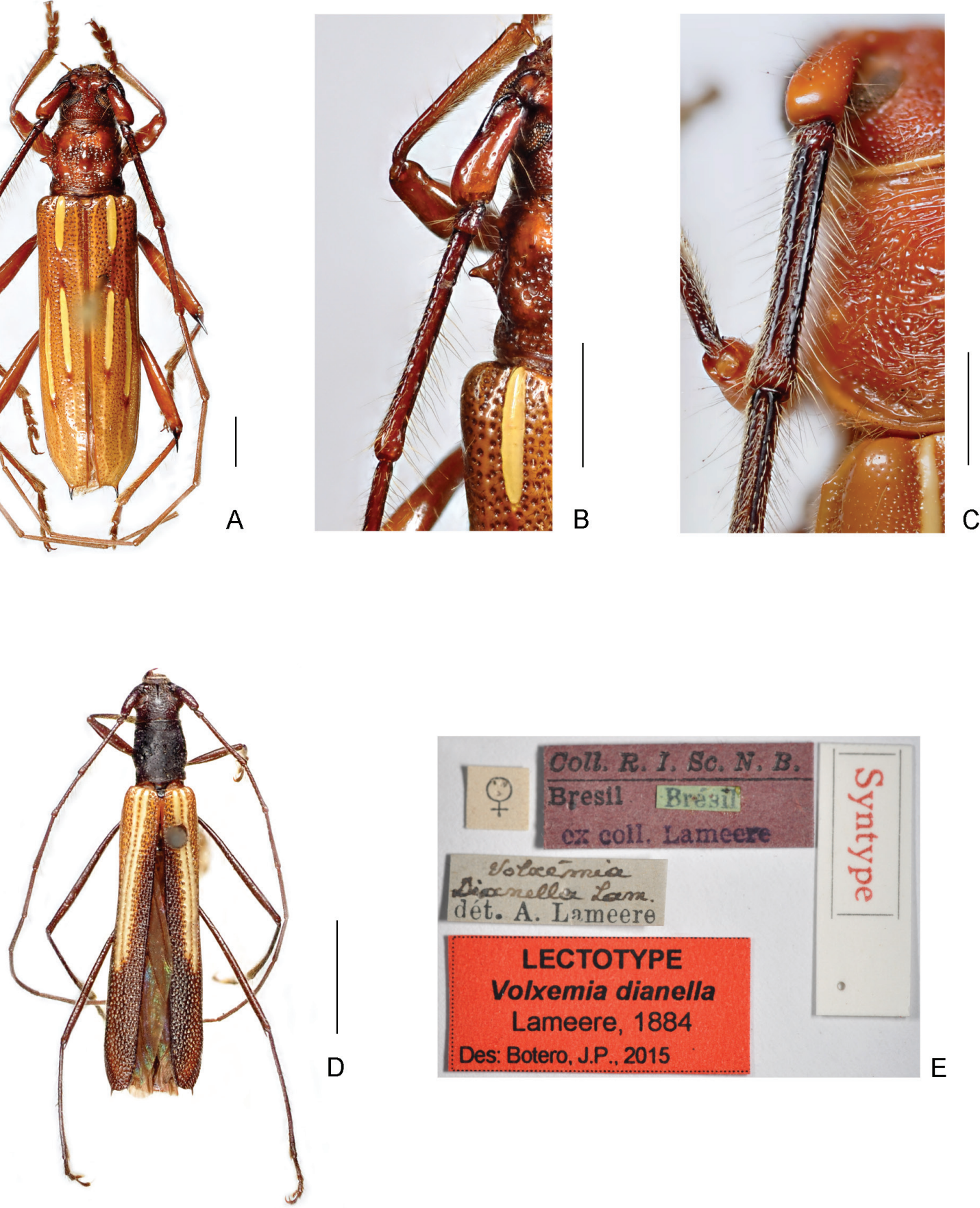

Fig. 3. A-B. Quiacaua vespertina (Monné \& Martins, 1973) comb. nov., đ̂. A. Dorsal view. B. Detail of antennomere III. - C. Eburodacrys longilineata White, 1853, detail of antennomere III. D-E. Volxemia dianella Lameere, 1884, lectotype. D. + , dorsal view. E. Lectotype labels. Scale bars = $2 \mathrm{~mm}$. 
- Posterior-central callus of pronotum flattened or weakly elevated; eburneous callosities of elytra elliptical, central callosities contiguous, without black areas at the elytra

2. Pronotum with posterior-central spot black; mesosternum punctate; external-central eburneous callosities of elytra curved, involving external side of inner-central. Brazil (Minas Gerais, Espírito Santo, Rio de Janeiro)

- Pronotum without posterior-central spot black; mesosternum smooth; external-central eburneous callosities of elytra straight, not involving the inner-central. Brazil (Amazonas, Pará, Maranhão) Q. taguaiba Martins, 1997

Quiacaua vespertina (Monné \& Martins, 1973) comb. nov.

Fig. 3A-B

Eburodacrys vespertina Monné \& Martins, 1973: 147, fig. 3.

Eburodacrys vespertina - Napp \& Martins 1980: 86-87, fig. 19. - Martins 1997: 62; 1999: 310, fig. 185. - Monné 2005: 165. — Galileo, Martins \& Moyses 2008: 17.

\section{Geographical distribution}

Brazil (Minas Gerais, Espírito Santo). Herein are added new state records for Bahia and Rio de Janeiro (Brazil).

\section{Material examined}

BRAZIL, Bahia: Encruzilhada, "Estrada Rio-Bahia Km 965, Motel da Divisa 960 m”, 1 ðૈ, Nov.1974, Seabra \& Roppa leg. (MNRJ); Minas Gerais: Juiz de Fora, "Estrada Rio de Janeiro", 1 क , Jul. 1946, H. Zellibor leg. (MNRJ); Espírito Santo: Colatina, 1 q, Oct. 1976, A. Silva leg. (MNRJ); Linhares, 1 J, Oct. 1972. F. M. Oliveira leg. (MNRJ); Parque Sooretama, 2 우우, 2 Nov. 1964, Oliveira \& Seabra Leg. (MNRJ); 1 đ̂, Nov. 1967, F.M. Oliveira leg. (MNRJ); Rio de Janeiro: Rio de Janeiro (Floresta da Tijuca), 1 Oे, Jan. 1970, C.A Campos Seabra leg. (MNRJ); Rio de Janeiro (Corcovado), 1 ㅇ, 12 Dec. 1962, Alvarenga \& Seabra leg. (MNRJ).

\section{Remarks}

Eburodacrys White, 1853 is characterized by having a longitudinal sulcus at antennomere III (as in E. longilineata White, 1853, Fig. 3C). Quiacaua differs from Eburodacrys by the absence of the longitudinal sulcus. The study of the original description and the examination of many specimens of Eburodacrys vespertina allow me to propose the transfer of this species to the genus Quiacaua.

Genus Volxemia Lameere, 1884

Volxemia Lameere, 1884: 85.

Volxemia - Martins \& Napp 1979: 83. — Martins 1997: 59; 1999: 152. — Monné 2005: 172; 2012: 18.

Type species

Volxemia dianella Lameere, 1884 (monotypy).

Volxemia dianella Lameere, 1884

Fig. 3D-E

Volxemia dianella Lameere, 1884: 86. 
BOTERO J.P., New species and taxonomic and geographic notes in Eburiini

Volxemia dianella - Zajciw 1958: 686; 1974: 47. — Damoiseau \& Cools 1987: 10. - Martins 1999: 154, fig. 96. — Monné 2005: 172. — Galileo et al. 2008: 17, 118. — Monné et al. 2010: 239.

In the original description of Volxemia dianella Lameere, 1884, the author mentioned that the species was described with 3 specimens: " 1 + rapportée de Botafogo par Van Volxem; 1 ot et 1 ㅇ du Brésil, sans localité précise." (Lameere 1884). Damoiseau \& Cools (1987) in their work about the type material of Cerambycidae deposited in the IRSNB mentioned only two specimens of $V$. dianella: "2 syntypes, (6), Brésil: Botafogo, ex coll. Van Volxem \& Lacordaire". The number 6 refers to the faunistic region (Neotropical + Mexico).

Last year I had the opportunity to visit the Entomological Collection at the Institut Royal des Sciences Naturelles de Belgique, and corroborated the existence of only two type-specimens of Volxemia dianella Lameere, 1884, with no holotype originally designated. In order to promote nomenclatural stability and facilite further identifications of this species, a lectotype and paralectotype are herein designated.

\section{Material examined}

\section{Lectotype}

1 (Fig. 3D-E) (present designation): “o”, "Coll. R. I. Sc. N. B. / Bresil Bresil / ex. coll. Lameere" "Syntype", "Volxemia / Dianella Lam.", "det. Lameere" and "LECTOTYPE / Volxemia dianella / Lameere, 1884 / Des: Botero, J.P., 2015" (IRSNB).

\section{Paralectotype}

1 : "Coll. R. I. Sc. N. B. / Bresil Botafogo / ex. coll. C. Van Volxem", "Volxemia / Dianella! / Ann. Belg. 1884. / 28 p. 85-86.", "Type", "Syntype $+"$, and "PARALECTOTYPE / Volxemia dianella / Lameere, 1884 / Des: Botero, J.P., 2015” (IRSNB).

\section{New geographical records}

Beraba cheilaria (Martins, 1967)

\section{Geographical distribution}

Brazil (Mato Grosso do Sul), Bolivia (Cochabamba, Santa Cruz), Paraguay. A new state record from Mato Grosso (Brazil) is added.

\section{Material examined}

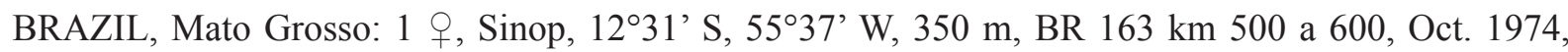
Alvarenga \& Roppa legs (MNRJ).

Beraba decora (Zajciw, 1961)

\section{Geographical distribution}

Brazil (Goiás, Maranhão, Piauí). A new state record from Mato Grosso (Brazil) is added.

\section{Material examined}

BRAZIL, Mato Grosso: 1 ภ̊, Jacaré (P.N. Xingú), Nov. 1961, Alvarenga \& Werner leg. (MNRJ). 
Eburella pumicosa Monné \& Martins, 1973

\section{Geographical distribution}

Brazil (Mato Grosso, Mato Grosso do Sul), Paraguay, Bolivia (Santa Cruz). A new state record from Rondônia (Brazil) is added.

\section{Material examined}

BRAZIL, Rondônia: 1 đૈ, Ouro Preto do Oeste, Oct. 1986, P. Magno \& J. Becker leg. (MNRJ)

Eburia crinita Noguera, 2002

\section{Geographical distribution}

Nicaragua, Panama. A new country record from Colombia (Bolivar) is added.

\section{Material examined}

COLOMBIA, Bolivar: 1 9, Zambrano, Hda. Monterrey, 70 m, 9³7’48” N, 7454’44’ W, F. Fernandez \& G. Ulloa leg. (IAVH)

\section{Eburodacrys crassimana Gounelle, 1909}

\section{Geographical distribution}

Suriname, Brazil (Pará, Maranhão, Mato Grosso, Goiás, Mato Grosso do Sul, Piauí, Bahia to Santa Catarina), Bolivia (Santa Cruz), Paraguay, Argentina (Catamarca, Santiago del Estero, Mendoza, Misiones, Chaco). A new country record from Colombia (Vichada) is added.

\section{Material examined}

COLOMBIA, Vichada: 1 9, PNN Tuparro, Cerro Tómas, 5²1’ N, 6751’ W, 140 m, 21-31 Jan. 2001, "Malaise", W. Villalba leg. (IAVH).

Eburodacrys notula Gounelle, 1909

\section{Geographical distribution}

Brazil (Maranhão, Mato Grosso, Tocantins, Distrito Federal, Goiás, Minas Gerais), Bolivia. A new state record from Amazonas (Brazil) is added.

\section{Material examined}

BRASIL, Amazonas: 1 ㅇ, Manaus, ZF2 Km-14, Torre 02³5'21"S, 6006'55” W, 35 m, 13-16 Aug. 2004, "lençol: luz mista e BLB", J.A. Rafael, F.F. Xavier, A.R. Ururahy, A. Silva \& S. Trovisco legs (INPA).

\section{Eburodacrys sexmaculata (Olivier, 1790)}

\section{Geographical distribution}

Venezuela, Ecuador, Suriname, Guyana, French Guiana, Peru, Bolivia, Brazil (Amazonas to Rio Grande do Sul, Mato Grosso do Sul). A new country record from Colombia (Putumayo and Vichada) is added. 
BOTERO J.P., New species and taxonomic and geographic notes in Eburiini

\section{Material examined}

COLOMBIA, Putumayo: 1 đ, Mocoa, 16 Aug. 1978, M. Cooper leg. (BMNH); Vichada: 1 ô, 2 우, PNN Tuparro, Bosque Sabana, 521' N, 6751' W, 100 m, 17-26 Dec. 2000, “Malaise”, W. Villalba leg. (IAVH); 1 đ, 21-31 Jan. 2001, "Malaise", W. Villalba leg. (IAVH).

\section{Eburodacrystola pickeli (Melzer, 1928)}

\section{Geographical distribution}

Brazil (Rondônia, Maranhão, Piauí, Ceará, Pernambuco, Minas Gerais), Bolivia (Santa Cruz). New state records from Mato Grosso, Pará and Rio Grande do Norte (Brazil) are added.

\section{Material examined}

BRAZIL, Mato Grosso: 2 우, Diamantino (Alto Rio Arinos), Oct. 1983, B. Silva leg. (MNRJ); 1

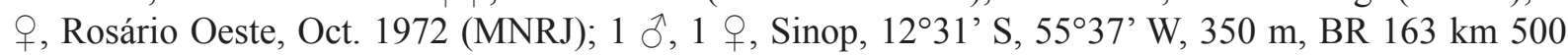
a 600, Oct. 1974, Alvarenga \& Roppa legs (MNRJ); 1 đૈ, same locality, Sep. 1978, Roppa \& Monné

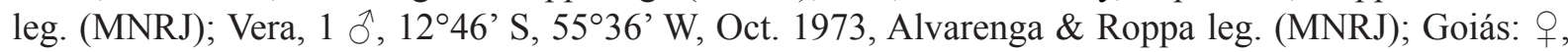
Campinaçu, 17 Oct. 1985, L.C. Alvarenga (MNRJ); Rio Verde, 1 đ̃, Oct. 1965, A. Maller leg. (MNRJ); Pará: Cachimbo, 1 đิ, 25-29 Oct. 1956, Travassos-Oliveira \& Adão leg. (MNRJ); Rio Grande do Norte: 1 đ , 1 ㅇ, Jardim de Angicos, Oct. 1952 (MNRJ); Natal, 1 ㅇ, 15 Jan. 1949, M. Alvarenga leg. (MNRJ); 1 , , Jan. 1950, Alvarenga leg. (MNRJ).

\section{Opades costipennis (Buquet, 1844)}

\section{Geographical distribution}

French Guiana, Suriname, Colombia, Ecuador, Brazil (Amapá, Amazonas, Pará, Rondônia, Maranhão). A new country record from Peru (Ucayali department) is added.

\section{Material examined}

PERU, Ucayalli: 1 \&, Pucallpa, 27 Sep. 1950, H. Zellibor leg. (MNRJ).

$$
\text { Quiacaua abacta (Martins, 1981) }
$$

\section{Geographical distribution}

Brazil (Espírito Santo, Rio de Janeiro). A new state record from Minas Gerais (Brazil) is added.

\section{Material examined}

BRAZIL, Minas Gerais: 1 đ, Jaboticatubas (Serra do Cipó), 21-24 Nov. 2000, U. Caramaschi leg. (MNRJ); Teófilo Otoni, 1 §ૈ, Nov. 1974, S.P, Nascimento leg. (MNRJ)

$$
\text { Styliceps sericata (Pascoe, 1859) }
$$

\section{Geographical distribution}

Mexico (Jalisco), Nicaragua, Costa Rica, Panama, Ecuador, Guyana, French Guiana, Brazil (Amazonas, Pará), Peru, Bolivia (Cochabamba, Santa Cruz). A new state record from Mato Grosso (Brazil) is added.

\section{Material examined}

BRAZIL, Mato Grosso: 1 + Cotriguaçu (Fazenda São Nicolau), 11 Dec. 2005, F. Vaz de Mello leg.

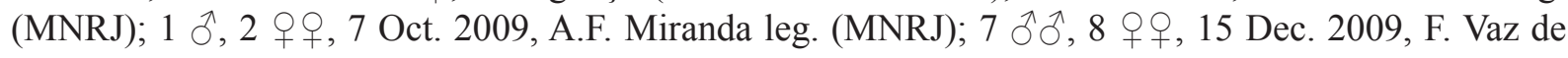
Mello leg. (MNRJ). 
Uncieburia nigricans (Gounelle, 1909)

\section{Geographical distribution}

Brazil (Piauí, Ceará, Mato Grosso, Goiás, Maranhão, Mato Grosso do Sul, Minas Gerais, São Paulo), Bolivia (Santa Cruz, Tarija). New state records from Alagoas and Paraíba (Brazil) are added.

\section{Material examined}

BRAZIL, Paraiba: Juazeirinho, 1 § , 21-23 Mar. 1957, F. Assis Silva leg. (MNRJ); Alagoas: 1 , Delmiro Gouveia, 1940 (MNRJ)

Uncieburia quadrilineata (Burmeister, 1865)

\section{Geographical distribution}

Brazil (Paraíba, Minas Gerais ) (?), Argentina (Salta, Santiago del Estero, Mendoza, Entre Ríos, Buenos Aires), Paraguay, Uruguay. A new state record from Mato Grosso do Sul (Brazil) is added.

\section{Material examined}

BRAZIL, Mato Grosso do Sul: 1 đ̊, Campo Grande, Parque dos Poderes, $20.446195^{\circ} \mathrm{S}, 54.559479^{\circ} \mathrm{W}$, 9 Nov. 2012, Ferraro, A. leg. (MNRJ)

Uncieburia rogersi (Bates, 1870)

\section{Geographical distribution}

Brazil (Roraima, Bahia to Paraná, Rio Grande do Sul), Bolivia (Santa Cruz), Paraguay. A new country record from Argentina (Misiones province) is added.

\section{Material examined}

Argentina, Misiones: 1 \&, Eldorado, Mar. 1944 (MNRJ).

\section{Acknowledgements}

The author is grateful to Dr. Miguel A. Monné (MNRJ) and Dr. Steven Lingafelter (U.S. Department of Agriculture, Smithsonian Institution) for providing helpful comments on the manuscript, to Steven Lingafelter for reviewing the English text, to Dr. Alain Drumont (IRSNB), to Larry Bezark, and to Fabio Arturo Gonzalez and Diana Espitia Reina (IAVH) who provided the specimens for description, to Dr. Crystal Maier (Field Museum of Natural History, Chicago, USA) for the photographs of the holotype of Eburia stroheckeri, to Larry Bezark, who measured most of the paratypes of Beraba hovorei sp. nov., to anonymous referees for reviewing the manuscript and providing valuable insights and to Conselho Nacional de Desenvolvimento Científico e Tecnológico (CNPq) by the postdoctoral fellowship (process number 168122/2014-6).

\section{References}

Arnett R.H. 1962. The beetles of the United States. Catholic Univ. America Press, Washington, D.C.

Audinet-Serville J.G. 1834. Nouvelle classification de la famille des longicornes (suite). Annales de la Société Entomologique de France 3: 5-110.

Bates H.W. 1870. Contributions to an insect fauna of the Amazon Valley (Coleoptera: Cerambycidae). The Transactions of the Entomological Society of London 1870: 243-335. 
BOTERO J.P., New species and taxonomic and geographic notes in Eburiini

Bates H.W. 1880. Longicornia. In: Biologia Centrali-Americana, Insecta, Coleoptera. Vol. V: 17152. R.H. Porter, London. http://www.sil.si.edu/DigitalCollections/bca/navigation/bca 12 205 00/ bca $12 \quad 0500$ select.cfm

Blanchard C.E. 1845. Histoire des insectes, traitant de leurs moeurs et de leurs métamorphoses en général, et comprenant une nouvelle classification fondée sur leurs rapports naturels. Didot, Paris. http://dx.doi.org/10.5962/bhl.title.35820

Blanchard C.E. 1851. Fauna Chilena, Insectos, Coleópteros. In: Gay C. História fisica y politica de Chile, Zoologia, Vol. V.: 285-563. Paris, Zoologia. http://www.biodiversitylibrary.org/item/55392

Blatchley W.S. 1910. On the Coleoptera known to occur in Indiana. An illustrated descriptive catalogue of the Coleoptera or beetles (exclusive of the Rhynchophora) known to occur in Indiana. Bulletin of the Indiana Department of Geological and Natural Resources 1: 1-1386.

Botero J.P. 2013. Description of the male of Eburella pinima Martins and notes on the geographical distribution of Eburodacrys aenigma Galileo \& Martins and Eburodacrys lanei Zajciw (Coleoptera, Cerambycidae). Revista Brasileira de Entomologia 57: 431-432. http://dx.doi.org/10.1590/S0085$\underline{56262013005000040}$

Botero J.P. 2014. Review of the genus Susuacanga (Coleoptera, Cerambycidae, Cerambycinae). Zootaxa 3779: 518-528. http://dx.doi.org/10.11646/zootaxa.3779.5.2

Botero J.P. 2015. Pseudeburia, a new South American genus of longhorned beetle (Cerambycidae, Cerambycinae, Bothriospilini). Journal of Natural History 49: 2583-2587. http://dx.doi.org/10.1080/ $\underline{00222933.2015 .1038328}$

Bousquet Y. 2007. Nomenclature and bibliographical notes on Cerambycidae (Coleoptera). The Coleopterists Bulletin 61: 616-631.

Bradley J.C. 1930. A manual of the genera of beetles of America north of Mexico. Keys for the determination of the families, tribes and genera of Coleoptera with a systematic list of the genera and higher groups. Daw, Illston \& Co., Ithaca.

Browne D.J. \& Peck S.B. 1996. The long-horned beetles of south Florida (Cerambycidae Coleoptera): biogeography and relationships with the Bahama Islands and Cuba. Canadian Journal of Zoology 74 (12): 2154-2169. http://dx.doi.org/10.1139/z96-244

Chemsak J.A. 1977. A list of types of Cerambycidae at the Field Museum of Natural History, Chicago (Coleoptera). The Coleopterists Bulletin 31: 173-179.

Chemsak J.A. \& Linsley E.G. 1963. The genera of hesperophanine Cerambycidae presently known from Mexico, with descriptions of several new species. Journal of the Kansas Entomological Society 36: 207-230.

Chemsak J.A., Linsley E.G. \& Noguera F.A. 1992. Listados faunísticos de México. II. Los Cerambycidae y Disteniidae de Norteamérica, Centroamérica y las Indias Occidentales (Coleoptera). Universidad Nacional Autónoma de México, México, Distrito Federal.

Chenu J.C. 1870. Encyclopédie d'histoire naturelle, ou traité complet de cette science d'aprés les travaux des naturalistes les plus éminents de tous les pays et de tous les époques. Vol. 3, Coléoptères. Firmin-Didot, Paris. http://dx.doi.org/10.5962/bhl.title.3539

Damoiseau R. \& Cools J. 1987. Liste du material typique conserve dans les collections entomologiques de 1'Institut royal des Sciences Naturelles de Belgique. Coleoptera, Cerambycoidea: Cerambycidae: Aseminae, Cerambycinae, Disteniinae, Lepturinae, Parandrinae, Prioninae et Spondylinae. Documents de travail 42: 1-39. 
Galileo M.H.M. \& Martins U.R. 2000. Novos táxons e nova combinação em Cerambycinae (Coleoptera) sul-americanos. Papéis Avulsos de Zoologia 41: 155-172.

Galileo M.H.M., Martins U.R. \& Moyses E. 2008. Cerambycidae Sul-Americanos (Coleoptera). Suplemento 2. Museu de Zoologia, Universidade de São Paulo.

Gilmour E.F. 1968. The Coleoptera Cerambycidae of Curaçao, Aruba and Bonaire. Studies of the Fauna of Curação and other Caribbean Islands 25: 83-178.

Hope F.W. 1835. Characters and descriptions of several new genera and species of coleopterous insects. Transactions of the Zoological Society of London 1: 91-112. http://dx.doi.org/10.1111/j.1096-3642.1835. $\underline{\text { tb00607.x }}$

Hope F.W. 1843. Observations on the Stenochoridae of New Holland, with Descriptions of New Genera and Species of that Family. The Transactions of the Zoological Society of London 3: 187-202.

Knull J.N. 1946. The long-horned beetles of Ohio (Coleoptera, Cerambycidae). Bulletin of the Ohio Biological Survey 39: 133-354.

Knull J.N. 1949 New Coleoptera with notes (Elateridae, Buprestidae and Cerambycidae). The Ohio Journal of Science 49: 102-104.

Lacordaire J.T. 1830. Mémoire sur les habitudes des insectes coléoptères de l'Amérique méridionale. Annales des Sciences Naturelles 21: 149-194.

Lacordaire J.T. 1868. Histoire Naturelle des Insectes. Genera des Coléoptères, ou exposé méthodique et critique de tous les genres proposés jusqu'ici dans cet ordre d'insectes, Vol. 8. Librairie Encyclopédique de Roret, Paris. http://dx.doi.org/10.5962/bhl.title.67686

Lameere A.A. 1884. Longicornes recueillis par feu Camille Van Volxem au Brésil et à La Plata. Annales de la Société Entomologique de Belgique 28: 83-99.

Laporte F.L.N. 1840. Histoire Naturelle des Insectes Coléoptères. Duménil, Paris.

LeConte J.L. 1850. An attempt to classify the longicorn Coleoptera of the part of America, north of Mexico. Journal of the Academy of Natural Sciences of Philadelphia 2: 5-38.

LeConte J.L. 1873a. New species of North American Coleoptera. Prepared for the Smithsonian Institution. Part II. Smithsonian Miscellaneous Collections 11: 169-240. http://dx.doi.org/10.5962/bhl. $\underline{\text { title. } 17758}$

LeConte J.L. 1873b. Classification of the Coleoptera of North America. Part II. Smithsonian Miscellaneous Collections 11: 279-348.

LeConte J.L. \& Horn G. H. 1883. Classification of the Coleoptera of North America. Prepared for the Smithsonian Institution. Smithsonian Miscellaneous Collections 26 (507), Smithsonian Institution, Washington D.C. http://dx.doi.org/10.5962/bhl.title.41105

Leng C.W. 1884. Synopses of the Coleoptera (Cerambycidae). Bulletin of the Brooklyn Entomological Society 8: 112-116.

Linsley E.G. 1962. The Cerambycidae of North America. Part III. Taxonomy and classification of the subfamily Cerambycinae, tribes Opsimini through Megaderini. University of California Publications in Entomology 20: 1-188. University of California, U.S.A.

Martins U.R. 1997. Contribuições para uma revisão das espécies sul-americanas da tribo Eburiini (Coleoptera, Cerambycidae). Revista Brasileira de Entomologia 41 (1): 57-83.

Martins U.R. 1999. Tribo Eburiini. In: Martins U.R. (org.) Cerambycidae Sul-americanos (Coleoptera) Taxonomia: 119-391. Sociedade Brasileira de Entomologia, São Paulo. 
BOTERO J.P., New species and taxonomic and geographic notes in Eburiini

Martins U.R. \& Galileo M.H.M. 1999. Novas espécies de Cerambycidae (Coleoptera) neotropicais. Revista Brasileira de Zoologia 16: 807-820. http://dx.doi.org/10.1590/s0101-81751999000300017

Martins U.R. \& Napp D.S. 1979. Delemodacrys mourei, gen. n., sp. n., com a revalidação de Eburiini (Coleoptera, Cerambycidae). Dusenia 11: 91-94.

Monné M.A. 1993. Catalogue of the Cerambycidae (Coleoptera) of the Western Hemisphere. Part II. Subfamily Cerambycinae: Tribes Hesperophanini and Eburiini. Sociedade Brasileira de Entomologia, São Paulo.

Monné M.A. 2005. Catalogue of the Cerambycidae (Coleoptera) of the Neotropical Region. Part I. Subfamily Cerambycinae. Zootaxa 946: 1-765.

Monné M.A. 2012. Catalogue of the type-species of the genera of the Cerambycidae, Disteniidae, Oxypeltidae and Vesperidae (Coleoptera) of the Neotropical Region. Zootaxa 3213: 1-183.

Monné M.A. 2015. Catalogue of the Cerambycidae (Coleoptera) of the Neotropical region. Part II. Subfamily Lamiinae. Available from http://cerambyxcat.com/ [accessed 20 Jul. 2015].

Monné M.A. \& Giesbert E.F. 1994. Checklist of the Cerambycidae and Disteniidae (Coleoptera) of the Western Hemisphere. Wolfsgarden Books, Burbank.

Monné M.A. \& Martins U.R. 1973. Notas e descrições em Eburiini (Coleoptera, Cerambycidae). Papéis Avulsos de Zoologia 27: 145-155.

Monné M.L., Monné M.A., Martins R.S., Simões M.V.P. \& Machado V.S. 2010. Espécies de Cerambycidae (Insecta, Coleoptera) ocorrentes no Estado do Rio de Janeiro (Brasil). Arquivos do Museu Nacional 67: 235-251.

Napp D.S. \& Martins U.R. 1980. Sinonímias, descrições e chave para espécies de Eburodacrys White, 1853 (Coleoptera, Cerambycidae). Papéis Avulsos de Zoologia 33 (4): 77-97.

Noguera F.A. 2002. Revisión taxonómica de las espécies del género Eburia Lepeletier y A. Serville in Lacordaire de Norte y Centroamérica (Coleoptera, Cerambycidae). Folia Entomologica Mexicana 41(Supl. 1): 1-167.

Peck S.B. \& Thomas M.C. 1998. A distributional checklist of the beetles (Coleoptera) of Florida. Arthropods of Florida and Neighboring Land Areas 16: 1-180.

Strauch A. 1861. Catalogue Systématique de tous les Coléoptères décrits dans les Annales de la Société Entomologique de France depuis 1832 jusqu'à 1859. H.W. Schmidt, Libraire-Éditeur, Halle.

Tavakilian G.L. 2013. Nouveaux actes nomenclaturaux pour 2013 / New nomenclatural changes for 2013 (Coleoptera, Cerambycidae). Les cahiers Magellenes 12: 108-111.

Thomas M.C. 1999. The genus Eburia Audinet-Serville in Florida (Coleoptera, Cerambycidae). Entomology Circular 396: 1-4.

Thomson J. 1861. Essai d'une classification de la famille des cérambycides et matériaux pour servir a une monographie de cette famille. Bouchard-Huzard, Paris. http://dx.doi.org/10.5962/bhl.title.9206

Thomson J.1864. Systema cerambycidarum ou exposé de tous les genres compris dans la famille des cérambycides et familles limitrophes. Mémoires de la Société Royale des Sciences de Liège 19: 1-352. http://dx.doi.org/10.5962/bhl.title.82379

Touroult J. 2012. Longicornes des Petites Antilles: mise à jour des connaissances. ACOREP France, Coléoptères des Petites Antilles 1: 70-85.

Touroult J. 2014. Nouveautés taxonomiques et faunistiques concernant les longicornes des Petites Antilles (Coleoptera, Cerambycidae). ACOREP France, Coléoptères des Petites Antilles 2: 82-89. 
Villiers A. 1980. Une collection de coléoptères Cerambycidae de la Dominique appartenant à l'U.S. National Museum (Washington). Annales de la Société Entomologique de France 16: 129-131.

Vitali F. 2007. Notes and taxonomic corrections to the Beiträge von Insektenfauna von Jamaika, Cerambycidae (Coleoptera, Cerabycidae). Entomapeiron 1: 37-59.

Zajciw D. 1958. Estudos sôbre longicórneos neotrópicos (Coleoptera, Cerambycidae). Memorias do Instituto Oswaldo Cruz 56: 685-693.

Zajciw D. 1974. Contribuição para o estudo da fauna dos longicórneos (Coleoptera, Cerambycidae) das florestas do Estado do Espírito Santo e principalmente da Reserva Biológica Soôretama. Boletim Técnico do Instituto Brasileiro de Desenvolvimento Florestal, Rio de Janeiro 4: 37-91.

Zayas F. 1975. Revisión de la família Cerambycidae (Coleoptera, Phytophagoidea). Academia de Ciencias de Cuba, Habana.

Manuscript received: 16 July 2015

Manuscript accepted: 7 September 2015

Published on: 29 October 2015

Topic editor: Koen Martens

Desk editor: Kristiaan Hoedemakers

Printed versions of all papers are also deposited in the libraries of the institutes that are members of the EJT consortium: Muséum national d'Histoire naturelle, Paris, France; Botanic Garden Meise, Belgium; Royal Museum for Central Africa, Tervuren, Belgium; Natural History Museum, London, United Kingdom; Royal Belgian Institute of Natural Sciences, Brussels, Belgium; Natural History Museum of Denmark, Copenhagen, Denmark. 